6 - ORIGINAL ARTICLE

ISCHEMIA-REPERFUSION

\title{
Remifentanil protects uterus against ischemia-reperfusion injury in rats ${ }^{1}$
}

\author{
Yunus Oktay Atalay, Serap Aktas ${ }^{I I}$, Sadik Sahin ${ }^{I I I}$, Zafer Kucukodaci ${ }^{\text {IV }}$, Ozlem Bingol Ozakpinar
}

DOI: http://dx.doi.org/10.1590/S0102-865020150110000006

\begin{abstract}
IAssistant Professor, Department of Radiology, Outpatient Anesthesia Service, Ondokuz Mayis University, Samsun, Turkey. Design of the study, statitics analysis, manuscript writing, critical revision, final approval.

IIMD, Department of Anesthesiology, The Private Emsey Hospital, Istanbul, Turkey. Technical procedures.

IIIMD, Department of Obstetrics and Gynecology, Zeynep Kamil Gynecologic and Pediatric Training and Research Hospital, Istanbul, Turkey. Conception and design of the study, analysis and interpretation of data.

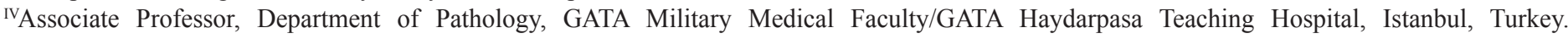
Histopathological examinations.

${ }^{\mathrm{V}} \mathrm{PhD}$, Department of Biochemistry, School of Pharmacy Marmara University, Istanbul, Turkey. Technical procedures, biochemical examinations.
\end{abstract}

\section{ABSTRACT}

PURPOSE: To investigate the effects of remifentanil as an antioxidant and analyze the histopathologic, biochemical changes in experimental ischemia-reperfusion $(\mathrm{I} / \mathrm{R})$ exposed rat uteri.

METHODS: Wistar albino rats were assigned to three groups $(n=7)$. $2 \mathrm{~h}$ period of ischemia was followed by $1 \mathrm{~h}$ of reperfusion in the I/R and the I/R-remifentanil groups. After ischemia, no drug was administered in the sham and I/R groups. In the I/R-remifentanil group, remifentanil infusion $(2 \mu \mathrm{g} / \mathrm{kg} / \mathrm{min})$ was started in the ischemia period, and continued until the end of reperfusion. After the ischemic and reperfusion period, the ischemic uterine horns were removed surgically for biochemical and histopathologic examination. Tissue damage scores (endometrial epithelial glandular leukocytosis, degeneration, and endometrial stromal changes) were examined. Malondialdehyde levels and catalase, superoxide dismutase enzyme activities in tissue were measured.

RESULTS: We found significantly lower epithelial leukocytosis and cell degeneration in the I/R-remifentanil group ( $<<0.05$ ). Remifentanil administration significantly decreased concentrations of malondialdehyde, and increased catalase and superoxide dismutase enzyme activities $(\mathrm{p}<0.05)$.

CONCLUSION: Remifentanil appears to protect the uterine tissue against ischemia-reperfusion and can be used safely in uterus transplantation.

Key words: Ischemia. Reperfusion Injury. Uterus. Transplantation. Rats. 


\section{Introduction}

Important advances in transplantation surgery have occurred during the last few decades. These achievements introduced non-life-saving transplantation of several organs and tissue such as the face, hand, larynx, lower limb, and uterus that will enhance the patient's quality of life ${ }^{1}$. Uterus transplantation is ideal for patients with uncorrectable uterine factor infertility. Successful uterine transplantation has been reported in animals (mice, sheep, and rats) ${ }^{2-4}$. The first attempt in humans was made in 2000, however, that uterus was removed because of uterine prolapse and necrosis ${ }^{5}$. There also some successful attempts of uterus transplantations in humans from cadaver, and livingdonors $^{6}$.

Transplant success is limited by ischemia-reperfusion (I/R) injury. I/R injury, which is mediated by reactive oxygen species (ROS), involves cell damage, apoptosis, and inflammatory events (thrombogenesis and microcirculation disturbances) ${ }^{7}$. The injury hypothesis holds that reperfusion injury plays an important role not only in acute but also in chronic rejection. The incidence of acute rejection can be reduced by intraoperative treatment of posthischemic reperfusion injury, which improves the long-term graft outcome ${ }^{8}$. Therefore, recognizing the preventive effects of drugs on organ damage during $\mathrm{I} / \mathrm{R}$ is clinically important in transplantation surgery. To date, some studies have investigated the protective effect of drugs against uterine I/R injury ${ }^{6}$. However, the effects of the intravenous anesthetic agents used during surgery have not been investigated. This is important information for anesthesiologists and surgeons that may be able to increase transplant success.

Remifentanil, a commonly used, ultrashort-acting opioid analgesic, has gained popularity in the field of anesthesia. Remifentanil can suppress the inflammatory response in a septic mouse model, reduce hepatic I/R injury, and can be a preferable agent in liver transplantation 9 . Thus, this analgesic can also provide protection in the uterus. Therefore, we decided to perform an experimental study to investigate the possible effects of remifentanil on I/R-induced uterine damage. The results of this study may provide guidance for choosing the appropriate opioid in uterus transplantation.

\section{Methods}

The experimental protocol was approved by the Institutional Animal Care and Use Committee of Marmara
University, Istanbul, Turkey, and was conducted according to the tenets of the Declaration of Helsinki. Assuming a statistical power of $100 \%$ and an alpha of $6 \%$, seven rats were required in each group to reach a level of significance ${ }^{6}$. We conducted the study with 21 female Wistar albino rats (8- to 10-weeks-old) weighing 220-270g in the Experimental Animals and Application Research Center of Marmara University, Istanbul, Turkey. The animals were fed ad libitum, housed in pairs in steel cages in a temperaturecontrolled environment $\left(22 \pm 1^{\circ} \mathrm{C}\right)$, and exposed to a $12 \mathrm{~h} / 12 \mathrm{~h} \mathrm{light} /$ dark cycle. The animals were all in the diestrus phase of the estrous cycle, which was determined with a vaginal smear as described by Marcondes et al. ${ }^{10}$. All rats were randomly allocated into three study groups: the sham group $(\mathrm{n}=7)$, the $\mathrm{I} / \mathrm{R}$ group $(\mathrm{n}=7)$, and the $\mathrm{I} / \mathrm{R}$ and remifentanil group $(\mathrm{I} / \mathrm{R}+\mathrm{R} ; \mathrm{n}=7)$.

Each rat was weighed and anesthetized with intramuscular ketamine hydrochloride (50 mg/kg Ketalar; Eczacibasi, Istanbul, Turkey) and xylazine hydrochloride (10 mg/kg Rompun; Bayer, Istanbul, Turkey), which were repeated as necessary to maintain anesthesia during the experiment. Following preoperative sterilization, laparotomy was performed in the midline area of the lower abdomen. The abdominal aorta was exposed, and uterine $\mathrm{I} / \mathrm{R}$ was produced by applying an atraumatic microvascular clamp (Bulldog clamp; Aesculap ${ }^{\circledR}$, B. Braun Melsungen) to the distal abdominal aorta. The clamp was placed just above the bifurcation of the iliac arteries and the vascular pedicle, $1 \mathrm{~cm}$ above and below the ovaries to occlude the collateral blood supply ${ }^{6}$. The abdomen was closed, and the wound was covered with moist gauze to minimize heat and fluid loss. In the sham group, only the laparotomy was performed. In the $\mathrm{I} / \mathrm{R}$ group, a $2-\mathrm{h}$ period of ischemia was followed by $1 \mathrm{~h}$ of reperfusion. In the $\mathrm{I} / \mathrm{R}+\mathrm{R}$ group, ischemia was performed as in the I/R group; however, a remifentanil infusion ( $2 \mu \mathrm{g} / \mathrm{kg} / \mathrm{min}$ ) was started via a previously cannulated tail vein catheter and continued until the end of the reperfusion ${ }^{11}$. At the end of reperfusion, both uterine horns were removed. The right uterine horn was used for histopathologic examination, and the left uterine horn was stored in a freezer at $-80^{\circ} \mathrm{C}$ for the biochemical analysis. The rats were sacrificed by decapitation.

\section{Histologic evaluation}

For the histopathologic analysis, uterine samples were fixed in $10 \%$ buffered formalin for $48 \mathrm{~h}$, dehydrated in an ascending alcohol series, cleared in xylene, and embedded in paraffin. Tissue 
sections ( $5 \mu \mathrm{m}$ thick) were stained with hematoxylin-eosin and Masson's trichrome for general morphologic analysis. Histologic assessments were performed with a photomicroscope (Olympus BX-51; Olympus Co, Tokyo, Japan) by the same pathologist who was blinded to the experimental groups. At least 10 histologic sections from the uterine tissue were assessed at a magnification of $\mathrm{x} 10$ and $\mathrm{x} 20$ objectives and then photographed. The scoring system for ovarian tissue, as defined by Sagsoz et al. ${ }^{12}$ was adapted to uterine tissue due to the limited studies on uterine ischemia reperfusion. Endometrial epithelial glandular (leukocytosis, cell degeneration) and endometrial stromal changes (congestion, edema) were scored from 0 to 3 according to the severity $(0=$ no pathological finding; 1 = pathological findings in $<33 \%$ of the uterine section; 2 = pathological findings in $33-66 \%$ of the uterine section; $3=$ pathological findings in $>66 \%$ of the uterine section).

\section{Biochemical evaluation}

The uterine tissue samples were homogenized with icecold $150 \mathrm{mmol} / \mathrm{L} \mathrm{KCl}$ for biochemical analyses and centrifuged at $3500 \times \mathrm{g}$ for $60 \mathrm{~min}$, and then the supernatant was collected. Catalase (CAT) activity was determined in the supernatant with an assessment of the rate constant of hydrogen peroxide decomposition at $240 \mathrm{~nm}^{13}$. Superoxide dismutase (SOD) activity was also determined in the supernatant layer according to Sun et $a l .{ }^{14}$ method. Activity was assessed with the inhibition of nitroblue tetrazolium reduction with xanthine-xanthine oxidase. One unit of SOD was defined as the amount of enzyme that causes $50 \%$ inhibition in the nitroblue tetrazolium reduction rate. The malondialdehyde (MDA) levels in the uterine tissue were studied in the homogenate and analyzed according to the reaction with thiobarbituric acid at $90-100^{\circ} \mathrm{C}$. MDA and thiobarbituric acid react together and produce a pink pigment with a maximum absorption of $532 \mathrm{~nm}$ in the thiobarbituric acid test reaction ${ }^{15}$.

\section{Statistical analysis}

Data analysis was performed with SPSS version 15.0 (SPSS Inc. Chicago, IL) for Windows. Data are expressed as means \pm standard error of the mean (SEM). The Kruskal-Wallis test for tissue scores and one-way analysis of variance (ANOVA) followed by Tukey's honest significant difference (HSD) test for biochemical results were used. The differences between groups were considered statistically significant at a $\mathrm{p}<0.05$.

\section{Results}

On the hematoxylin-eosin stained slides, dense leukocytosis was detected in the $\mathrm{I} / \mathrm{R}$ group (Figure $1 \mathrm{~A}$ ). In contrast, administration of remifentanil reduced the concentration of leukocytes $(\mathrm{p}=0.003)$ (Figure 1B). Epithelial cell degeneration decreased significantly in the group administered remifentanil compared with the $\mathrm{I} / \mathrm{R}$ group $(\mathrm{p}=0.001)$ (Figure 1B). There was a considerable difference in the stromal edema and vascular congestion scores between the sham and the I/R and I/R+R groups $(p<0.05)$. However, these scores were not statistically different when comparing the $I / R$ and $I / R+R$ groups ( $>0.05$ ). The degree of leukocytosis and epithelial cell degeneration in the groups are also shown in Figure 1C-D.

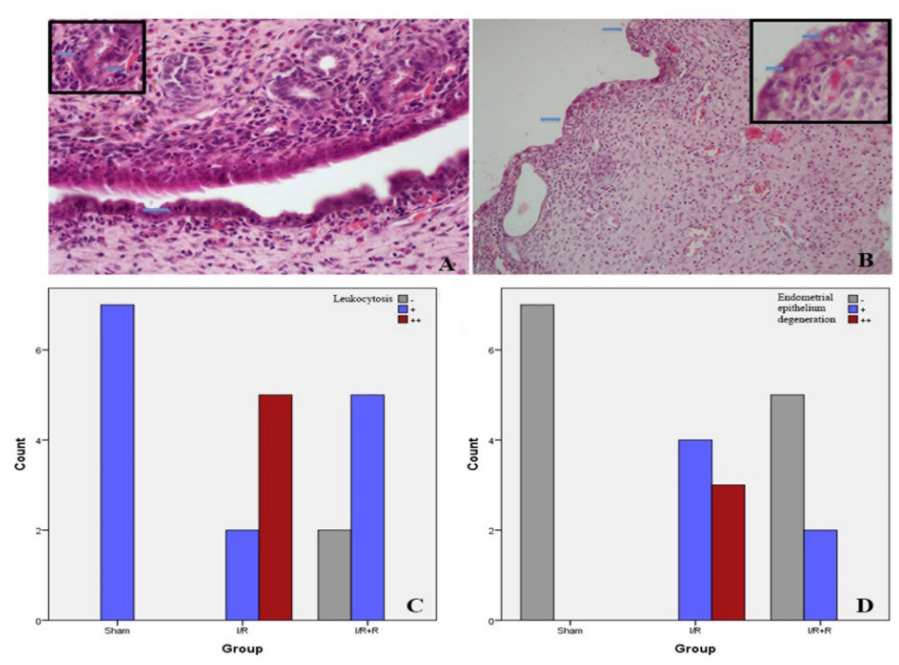

FIGURE 1 - Histopathological effects of ischemia reperfusion (I/R) and remifentanil in endometrium tissue. (A) On the hematoxylin-eosin stained slides, dense leukocytosis and increased epithelial cell degeneration (arrows) were detected in the $\mathrm{I} / \mathrm{R}$ group. (B) The remifentaniladministered group $(\mathrm{I} / \mathrm{R}+\mathrm{R})$ reduced the concentration of leucocytes and epithelial cell degeneration (arrows) (H\&E, original magnification x100, x200) (C-D). Bar graphics show the degree of leukocytosis and epithelial cell degeneration in the groups.

The MDA levels increased significantly in the I/R group compared with the sham group $(\mathrm{p}=0.001)$. Compared with the $\mathrm{I} / \mathrm{R}$ group, remifentanil administration significantly decreased the MDA levels $(p=0.000)$ (Figure 2$)$. CAT activity decreased in the $\mathrm{I} / \mathrm{R}$ group compared with the sham group $(\mathrm{p}=0.000)$. However, remifentanil administration considerably increased CAT activity compared with the $\mathrm{I} / \mathrm{R}$ group $(\mathrm{p}=0.000)$ (Figure 3$)$. As with 
the CAT activity, remifentanil also significantly increased SOD activity compared with the I/R group $(p=0.000)$ (Figure 4$)$.

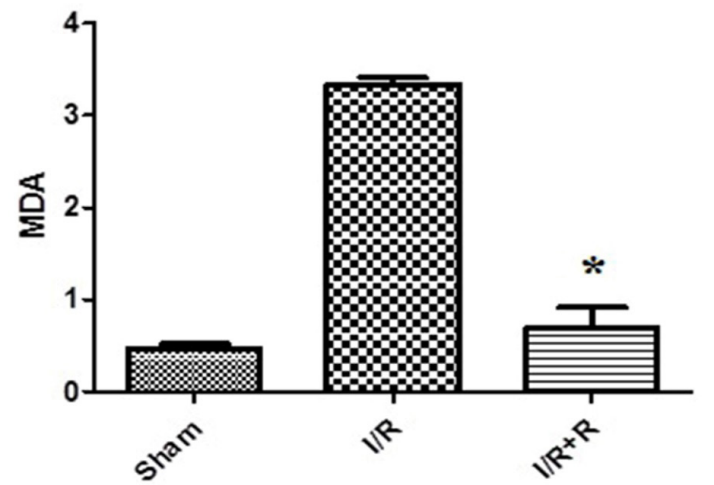

FIGURE 2 - Effect of remifentanil on malondialdehyde (MDA) levels. Remifentanil infusion $(2 \mu \mathrm{g} / \mathrm{kg} / \mathrm{min})$ was started with the ischemia period $(2 \mathrm{~h})$ and was continued until the end of reperfusion $(1 \mathrm{~h})$. Data expressed as mean \pm SEM. $\mathrm{p}=0.000 v s$ ischemia reperfusion (I/R) group.

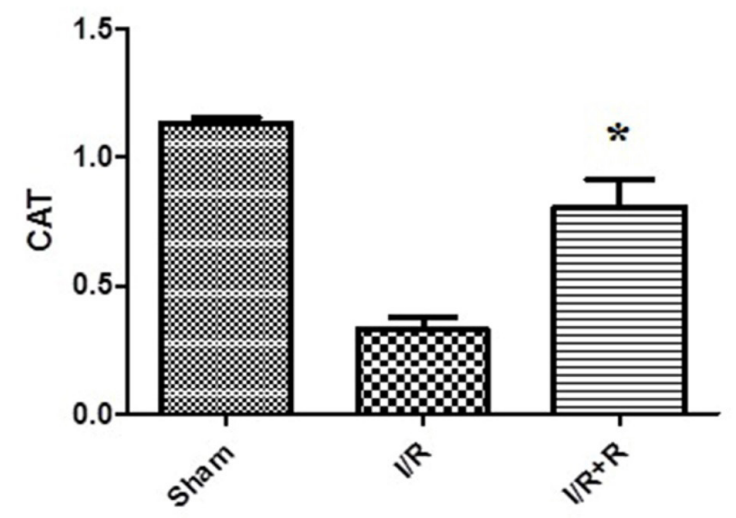

FIGURE 3 - Effect of remifentanil on catalase (CAT) activity. Remifentanil infusion $(2 \mu \mathrm{g} / \mathrm{kg} / \mathrm{min})$ was started with the ischemia period (2h) and was continued until the end of reperfusion (1h). Data expressed as mean \pm SEM. $\mathrm{p}=0.000 v s$ ischemia reperfusion (I/R) group.

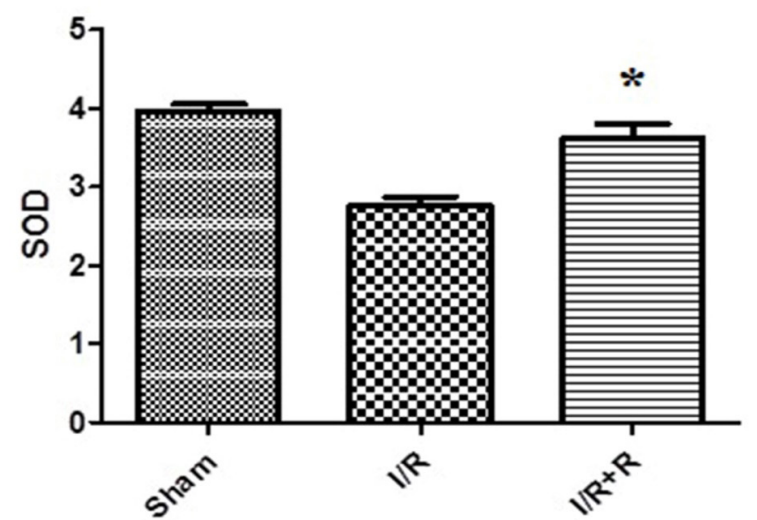

FIGURE 4 - Effect of remifentanil on superoxide dismutase (SOD) activity. Remifentanil infusion $(2 \mu \mathrm{g} / \mathrm{kg} / \mathrm{min})$ was started with the ischemia period $(2 \mathrm{~h})$ and was continued until the end of reperfusion (1h). Data expressed as mean \pm SEM. $\mathrm{p}=0.000 v s$ ischemia reperfusion (I/R) group.

\section{Discussion}

ROS-mediated reperfusion injury induces acute and chronic rejections. Treatment of the reperfusion injury is a successful therapeutic strategy in transplantation models ${ }^{16}$. In this study, the protective effect of remifentanil against uterine I/R was evaluated. Our results demonstrate that remifentanil administration decreased histopathologic injury levels and oxidative stress (MDA levels) and increased antioxidant enzyme (CAT, SOD) activity after uterine I/R injury. In this experimental study, we observed that remifentanil has beneficial effects in preventing reperfusion injury of uterine tissue.

Several experimental studies have shown a protective effect with opioid agonists against $\mathrm{I} / \mathrm{R}$ injury in a wide variety of tissues ${ }^{17}$. Many researchers administered remifentanil during ischemic preconditioning and postconditioning. Preconditioning refers to the application of a protective intervention before ischemia; this can be either pharmacological or mechanical, which includes brief periods of sublethal ischemia separated by periods of reperfusion to increase the tolerance of the tissue to I/ $\mathrm{R}^{18}$. The heart, liver, kidney, brain, and intestine are among the tissues in which remifentanil preconditioning has been studied. Studies have shown remifentanil has a protective effect against ischemic injury ${ }^{9,19}$. In a study of remifentanil preconditioning in liver $\mathrm{I} / \mathrm{R}$, the authors reported a protective effect as suggested by decreased apoptosis and less tissue damage, which is in agreement with our findings ${ }^{11}$. In the present study, the histopathologic evaluation revealed that the uterine I/R injury caused significant epidermal cell damage and significant leukocyte accumulation in the rat uterine tissue. In contrast, remifentanil administration decreased the leukocyte population and cell degeneration. Ischemic postconditioning initially refers to the application of a protective intervention after reperfusion. This technique is similar to preconditioning; only the time of the application differs ${ }^{20}$. Postconditioning with remifentanil has also shown protection in $\mathrm{I} / \mathrm{R}$ injury of the heart and brain $^{21,22}$. Protection occurs not only during preconditioning and postconditioning but also when remifentanil is given continuously ${ }^{23}$. Remifentanil is usually administered as a continuous infusion in current clinical practice; therefore, we preferred to administer the analgesic in this way.

Since oxygen is reintroduced during reperfusion, xanthine oxidase converts the excess hypoxanthine to toxic ROS, which results in cellular damage by lipid peroxidation ${ }^{24}$. Lipid peroxidation leads to the formation of lipid radicals, lipid hydroxyl radicals, and hydroperoxides. MDA serves as a sign 
of lipid peroxidation in $\mathrm{I} / \mathrm{R}$ damage. MDA disorganizes ionic transport and enzymatic activity that leads to increased membrane permeability, and causes breaks in cell content ${ }^{25}$. In this study, we found a significant decrease in MDA levels with remifentanil infusion. Consistent with our finding, in a study that investigated pharmacological preconditioning with remifentanil in liver $\mathrm{I} / \mathrm{R}$ injury, the authors also reported a decrease in MDA levels ${ }^{11}$. Similarly, in another study, remifentanil preconditioning decreased MDA levels in intestinal ischemia ${ }^{26}$. Antioxidants are among the defense mechanisms against free radical-induced oxidative stress. The enzymatic antioxidant defenses include glutathione peroxidase, $\mathrm{SOD}$, and $\mathrm{CAT}^{27}$. In the present study, CAT and SOD activities were used to determine the antioxidant levels. CAT, as an antioxidant enzyme, converts $\mathrm{H}_{2} \mathrm{O}_{2}$ to $\mathrm{H}_{2} \mathrm{O}-\mathrm{O}_{2}$ and prevents the formation of hydroxyl radicals. Studies with CAT showed that it can protect tissues and organs against I/R injury damage by its antioxidative ability ${ }^{28}$. SOD acts as an enzyme-free radical scavenger and can protect organs from reperfusion damage ${ }^{29}$. We found that remifentanil administration increased both CAT and SOD activities. Remifentanil appears to protect uterine tissues against I/R as evidenced by the decreased MDA concentrations and increased CAT and SOD activities.

A limitation of our study is that the model we used (2-h ischemia, 1-h reperfusion) does not reflect a clinical situation. Thus, further investigation is required to provide detailed information about the ischemia-reperfusion period as an experimental model.

We observed no differences in stromal edema and vascular congestion between the $I / R$ and $I / R+R$ groups. This may because of the stage of the reproductive cycle in rats. In the diestrus phase, the uterus is small, and the horns lack prominent vasculature. Additionally, only slight stromal edema can be observed at this time ${ }^{30}$. According to these data, it is possible that considerable differences will not be found between these groups.

\section{Conclusions}

The remifentanil administration can lead to protection against uterine ischemia-reperfusion. This study represents a step toward understanding the effect of remifentanil that is commonly used during transplantation surgery. Since the drugs used during transplantation are important, remifentanil can be used safely as an opioid. The next challenge is to better to find new experimental models that will mimic the clinical situation due to the limited studies on uterine ischemiareperfusion.

\section{References}

1. Brannstrom M, Diaz-Garcia C, Hanafy A, Olausson M, Tzakis A. Uterus transplantation: animal research and human possibilities. Fertil Steril. 2012;97(6):1269-76. PMID: 22542990.

2. Racho El-Akouri R, Wranning CA, Molne J, Kurlberg G, Brannstrom M. Pregnancy in transplanted mouse uterus after long-term cold ischaemic preservation. Hum Reprod. 2003;18(10):2024-30. PMID: 14507816.

3. Ramirez ER, Ramirez Nessetti DK, Nessetti MB, Khatamee M, Wolfson MR, Shaffer TH, Ramirez VZ, Ramirez HA. Pregnancy and outcome of uterine allotransplantation and assisted reproduction in sheep. J Minim Invasive Gynecol. 2011;18(2):238-45. PMID: 2135407.

4. Wranning CA, Akhi SN, Diaz-Garcia C, Brannstrom M. Pregnancy after syngeneic uterus transplantation and spontaneous mating in the rat. Hum Reprod. 2011;26(3):553-8. PMID: 21159686.

5. Fageeh W, Raffa H, Jabbad H, Marzouki A. Transplantation of the human uterus. Int J Gynaecol Obstet. 2002;76(3):245-51. PMID: 11880127.

6. Sahin S, Ozakpinar OB, Ak K, Eroglu M, Acikel M, Tetik S, Uras F, Cetinel S. The protective effects of tacrolimus on rat uteri exposed to ischemia-reperfusion injury: a biochemical and histopathologic evaluation. Fertil Steril. 2014;101(4):1176-82. PMID: 24502894.

7. Ozaki KS, Kimura S, Murase N. Use of carbon monoxide in minimizing ischemia/reperfusion injury in transplantation. Transplant Rev (Orlando). 2012;26(2):125-39. PMID: 22000659.

8. Land WG. The role of postischemic reperfusion injury and other nonantigen-dependent inflammatory pathways in transplantation. Transplantation. 2005;79(5):505-14. PMID: 15753838.

9. Yang LQ, Tao KM, Liu YT, Cheung CW, Irwin MG, Wong GT, Lv $\mathrm{H}$, Song JG, Wu FX, Yu WF. Remifentanil preconditioning reduces hepatic ischemia-reperfusion injury in rats via inducible nitric oxide synthase expression. Anesthesiology. 2011;114(5):1036-47. PMID: 21383616.

10. Marcondes FK, Bianchi FJ, Tanno AP. Determination of the estrous cycle phases of rats: some helpful considerations. Braz J Biol. 2002;62(4A):609-14. PMID: 12659010.

11. Zhao G, Shen X, Nan H, Yan L, Zhao H, Yu J, Lv Y. Remifentanil protects liver against ischemia/reperfusion injury through activation of anti-apoptotic pathways. J Surg Res. 2013;183(2):827-34. PMID: 23608616.

12. Sağsöz N, Kisa Ü, Apan A. Ischaemia-reperfusion injury of rat ovary and the effects of vitamin $\mathrm{C}$, mannitol and verapamil. Hum Reprod. 2002;17(11):2972-6. PMID: 12407059.

13. Aebi H. Catalase in vitro. Methods Enzymol. 1984;105:121-6. PMID: 6727660.

14. Sun Y, Oberley LW, Li Y. A simple method for clinical assay of superoxide dismutase. Clin Chem. 1988;34(3):497-500. PMID: 3349599.

15. Esterbauer H, Cheeseman KH. Determination of aldehydic lipid peroxidation products: malonaldehyde and 4-hydroxynonenal. Methods Enzymol. 1990;186:407-21. PMID: 2233308.

16. Land WG. The role of postischemic reperfusion injury and other nonantigen-dependent inflammatory pathways in transplantation. Transplantation. 2005;79(5):505-14. PMID: 15753838.

17. Minguet G, Brichant JF, Joris J. Opioids and protection against ischemia-reperfusion injury: from experimental data to potential clinical applications. Acta Anaesthesiol Belg. 2012;63(1):23-34. PMID: 22783707.

18. Riksen NP, Smits P, Rongen GA. Ischaemic preconditioning: from molecular characterisation to clinical application--part I. Neth J Med. 2004;62(10):353-63. PMID: 15683090. 
19. Vianna PT, Castiglia YM, Braz JR, Viero RM, Beier S, Vianna Filho PT, Vitoria A, Reinoldes Bizarria Guilherme G, de Assis Golim M, Deffune E. Remifentanil, isoflurane, and preconditioning attenuate renal ischemia/reperfusion injury in rats. Transplant Proc. 2009;41(10):4080-2. PMID: 20005344.

20. Zhao H. The Protective Effects of Ischemic Postconditioning against Stroke: From Rapid to Delayed and Remote Postconditioning. Open Drug Discov J. 2011;5:138-47. PMID: 23609459.

21. Kim H, Cho J, Hong S, Kim S, Shim J, Kwak Y. Remifentanil protects myocardium through activation of anti-apoptotic pathways of survival in ischemia-reperfused rat heart. Physiol Res. 2010;59(3):347-56. PMID: 19681651.

22. $\mathrm{Hu} \mathrm{X}$, Xie $\mathrm{C}, \mathrm{He} \mathrm{S}$, Zhang Y, Li Y, Jiang L. Remifentanil postconditioning improves global cerebral ischemia-induced spatial learning and memory deficit in rats via inhibition of neuronal apoptosis through the PI3K signaling pathway. Neurol Sci. 2013;34(11):1955-62. PMID: 23609459.

23. Chun KJ, Park YH, Kim JS, Jang Y, Kim JH, Kim J, Lee MY Comparison of 5 different remifentanil strategies against myocardial ischemia-reperfusion injury. $\mathrm{J}$ Cardiothorac Vasc Anesth. 2011;25(6):926-30. PMID: 21514843.

24. Collard CD, Gelman S. Pathophysiology, clinical manifestations, and prevention of ischemia-reperfusion injury. Anesthesiology. 2001;94(6):1133. PMID: 11465607.

25. Fukai M, Hayashi T, Yokota R, Shimamura T, Suzuki T, Taniguchi M, Matsushita M, Furukawa H, Todo S. Lipid peroxidation during ischemia depends on ischemia time in warm ischemia and reperfusion of rat liver. Free Radic Biol Med. 2005;38(10):1372-81. PMID: 15855055

26. Cho SS, Rudloff I, Berger PJ, Irwin MG, Nold MF, Cheng W, NoldPetry CA. Remifentanil ameliorates intestinal ischemia-reperfusion injury. BMC Gastroenterol. 2013;13(1):69. PMID: 23607370.

27. Valko M, Leibfritz D, Moncol J, Cronin MT, Mazur M, Telser J. Free radicals and antioxidants in normal physiological functions and human disease. Int J Biochem Cell Biol. 2007;39(1):44-84. PMID: 16978905 .

28. Chen B, Tang L. Protective effects of catalase on retinal ischemia/ reperfusion injury in rats. Expe Eye Res. 2011;93(5):599-606. PMID: 21824472.

29. Baker GL, Corry RJ, Autor A. Oxygen free radical induced damage in kidneys subjected to warm ischemia and reperfusion. Protective effect of superoxide dismutase. Ann Surg. 1985;202(5):628. PMID: 3840348 .

30. Westwood FR. The female rat reproductive cycle: a practical histological guide to staging. Toxicol Pathol. 2008;36(3):375-84. PMID: 18441260

\section{Acknowledgement}

To Turgut Sekerler $\mathrm{PhD}$ for overseeing the biochemical investigations.

\section{Correspondence:}

Yunus Oktay Atalay

Ondokuz Mayis University, Faculty of Medicine

Department of Radiology, Outpatient Anesthesia Service

Kurupelit, TR55139 Atakum, Samsun, Turkey

Phone: +90 5056762909

Fax: +90 3624576446

dryunusatalay@gmail.com

Received: July 11, 2015

Review: Sep 12, 2015

Accepted: Oct 15, 2015

Conflict of interest: none

Financial source: none

${ }^{1}$ Research performed at Experimental Animals and Application Research Center, Marmara University, Istanbul, Turkey. 